\title{
Role of Naked Eye Single Tube Red Cell Osmotic Fragility Test (NESTROFT) in Detecting Beta-Thalassemia Trait
}

\author{
A FERDOUSI $^{\mathrm{a}}, \mathrm{MAHMAD}^{\mathrm{b}}, \mathrm{JD}^{\mathrm{S}} \mathrm{SHARMA}^{\mathrm{c}}, \mathrm{R}^{\mathrm{SAMAD}}{ }^{\mathrm{d}}, \mathrm{AKMZ} \mathrm{ULLAH}^{\mathrm{e}}$
}

\begin{abstract}
Summary:
Thalassemia is one of the commonest inherited diseases in Bangladesh. The birth of a thalassemic child places considerable strain, not only on the affected child and its family but also on the community and the nation at large. To reduce the burden of the society and to reduce the disease incidence by providing genetic counseling, detection of carrier is important.
\end{abstract}

The present study evaluates the role of 'Naked Eye Single Tube Red Cell Osmotic Fragility Test' (NESTROFT) in detecting $\beta$-thalassemia trait.

The current study is a cross sectional study done during the period of September 2008 to August 2009. The study subjects were sibs, parents and relatives of thalassemia patients of age more than 1 year attending Pediatric

\section{Introduction:}

Thalassemia is the most common inherited gene disorder in the world and varies in different population groups in the world. ${ }^{1}$ Thalassemia is more prevalent in the Mediterranean basin, the Middle East, Southern eastern Asia, the South China, with reported carrier rates ranging from $2 \%$ to $25 \%$. Recent data indicate that about 300,000-500,000 children are born each year with the severe homozygous states of these diseases (World Bank 2006, report of a joint WHOMarch of Time meeting 2006).

Thalassemia is one of the commonest inherited disease in Bangladesh ${ }^{2}$. A conservative world report has

a. Dr. Asma Ferdousi, Junior Consultant (Pediatrics), Chittagong General Hospital, Chittagong.

b. Prof. Mainuddin Ahmad, Former Assoc. Prof. \& Head of Pediatrics, Chittagong Medical College, Chittagong.

c. Dr. Jhulan Das Sharma, Ex-Assoc. Prof. \& Head of Pediatrics, Chittagong Medical College, Chittagong.

d. Rasheda Samad, Professor of Pediatrics, Chittagong Medical College, Chittagong.

e. Dr. AKM Zafar Ullah, Senior Consultant (Pediatrics), Chittagong General Hospital, Chittagong.

Address of Correspondence: Dr. Asma Ferdousi, Junior Consultant ( Pediatrics), Chittagong General Hospital, Chittagong. E-mail: aferdousi71@gmail.com, Cell+8801824825800.

Received: 18 September, 2017

Accepted: 6 August, 2018 department of Chittagong Medical College Hospital. Sample size was 50. Here subjects with lowered osmotic fragility test were detected and later on Hb-electrophoresis was done. All the data were recorded and analyzed by SPSS programme. The Sensitivity, Specificity and predictive value of positive and negative tests were computed and they were $92.6 \%, 80 \%, 92.6 \%$ and $80 \%$ respectively. False positive cases were found.

The present study found NESTROFT to be both sensitive and reasonably specific and of high negative predictive value. However, multicenter study with large sample is needed to recommend NESTROFT as a single screening test for detection of $\beta$-thalassemia trait.

(J Bangladesh Coll Phys Surg 2018; 36: 145-152) DOI: http://dx.doi.org/10.3329/jbcps.v36i4.38182

estimated that 3 percent are carriers of betathalassemia and 4 percent are carriers of $\mathrm{Hb}-\mathrm{E}$ in Bangladesh $^{3}$. In Bangladesh, a study done on 735 school children the average prevalence of betathalassemia trait was $4.1 \%$ and $\mathrm{Hb}-\mathrm{E}$ trait was $6.1 \%$ in Bengali school children. Among tribal school children in Chittagong, the average of beta-thalassemia trait was $4.2 \%$ and $\mathrm{Hb}-\mathrm{E}$ trait was $41.7 \%{ }^{4} \mathrm{It}$ is presumed that approximately six thousands thalassemic children are born each year in Bangladesh ${ }^{1}$.

It's treatment is very cumbersome and costly. The only cure available today is bone marrow transplantation, which is risky and too costly for most of the patient. The cost of treatment for one thalassemic child in our country also approximately 70,000 to 90,000 taka per year ${ }^{5}$. Being a poor country, majority of thalassemia patients do not get adequate treatment.

The birth of a thalassemic child places considerable stain, not only on the affected child, but also on the family, community and the nation at large. With these limitations, emphasis must shift from treatment to prevention of such births in near future. This can reduce the disease incidence; hence reduce the burden of the society. 
The most effective approach is implementation of a carrier screening program offering genetic counseling, prenatal diagnosis and selective termination of affected fetus. ${ }^{6}$ Various screening parameters that are available include peripheral blood smear examination, red cell indices, ${ }^{7-9}$ osmotic fragility (quantitative), free red cell porphyrins ${ }^{10}, \mathrm{RBC}$ count $^{11}$ and $\mathrm{RDW}^{12}$. All these test, including $\mathrm{HbA}_{2}$ estimation (confirmatory) test for beta thalassemia trait, are expensive, time consuming and require sophisticated equipment. The need, therefore is for a simple, low cost rapid and reliable test which can be used for mass screening. NESTROFT is such a test used for detection of beta- thalassemia trait.

Various studies have been carried out in the world, especially in the developing countries similar to India, Myanmar, Iraq, Thailand ${ }^{13-16}$ to see sensitivity and specificity of NESTROFT. This study has been undertaken to determine the validity of simple and inexpensive method, NESTROFT as a screening test for detection of heterozygous beta- thalassemia.

\section{Methodology:}

Study design: It is a descriptive cross sectional study.

Place of study: The study was carried out in pediatric department of Chittagong Medical College and Hospital.

Period of study: One year starting from September 2008.

Time of data collection: 15th September 2008 to 15 th September 2009.

Study population: Sibs, parents and relatives of thalassemia patients attending pediatric department of Chittagong Medical College Hospital.

Sample size determination:Sample size was determined on the basis of the following formula. $N=Z^{2} p q$ Here, $N=$ Sample size

$e^{2} \quad Z=$ the value of standard variate at given confidence level Usually at 1.96 which corresponds to 95\% confidence limit.

$\mathrm{P}=$ Estimated prevalence which will be $4.1 \%$ $\mathrm{q}=1-\mathrm{p}$ that is $95.9 \%$ $\mathrm{e}=$ Acceptable error.

Thus, $\mathrm{N}=37762$

According to this formula, the calculated sample size is 37762 .
It became a big number for a single personto collect data and samples from the patients with in the decided time frame. Moreover, resource constrain is also an important factor. I therefore collected as many as possible, which was 50 in number.

Sampling technique:Sample was selected by nonprobability convenience sampling technique.

Research instrument: case record form.

\section{Inclusion criteria:}

Any one $>1$ year of age among sibs, parents and relatives of thalassemia patients.

\section{Exclusion criteria:}

1. Subjects suffering from $\mathrm{Hb}$-electrophoresis proved thalassemia or any other severe illness.

2. Subjects with moderate to severe anaemia.

3. Blood transfusion within last 90 days.

\section{Results:}

During the study period 50 subjects were screened. Among them 27 subjects were ${ }^{2}$-thalassemia trait, 11 subjects were $\mathrm{Hb}-\mathrm{E}$ trait, 10 were with normal hemoglobin and other 2 were Hb-E disease. Among the total 50 subjects, mild pallor was found in 9 subjects. Total NESTROFT positive cases were 30 and NESTROFT negative cases were 20 in number.

Among the total study subjects 28 (56\%) were female and $22(44 \%)$ were male. Female predominated in these series. Distribution of sex among the study subjects is shown in Table-I.

\section{Table-I}

\begin{tabular}{lcc} 
& $\begin{array}{c}\text { Distribution of sex among the study } \\
\text { subjects }(n=50)\end{array}$ \\
Sex & Frequency & Percentage (\%) \\
\hline Male & 22 & 44.0 \\
Female & 28 & 56.0 \\
\hline Total & 50 & 100.0 \\
\hline
\end{tabular}

Age ranged between 2 and 52 years with a mean age of $30.12 \pm 10.02$. Age distribution of the series is described in Table-II 
Table-II

Distribution of age among the study subjects $(n=50)$

\begin{tabular}{cccccc} 
Age (years) & $\mathrm{N}$ & Mean & \pm SD & Median & Range \\
\hline 50 & 30.12 & 10.02 & 30.50 & $2 " 52$ \\
\hline
\end{tabular}

Relation of study subjects with thalassemia patients was various. Among them no. of mother, father, brother, uncle, sister and aunt were respectively 22 (44\%), 14 (28\%), $4(8 \%), 4(8 \%), 3(6 \%)$ and $3(6 \%)$. Distribution of relation with thalassemia patients is shown in Bar Chart-01.

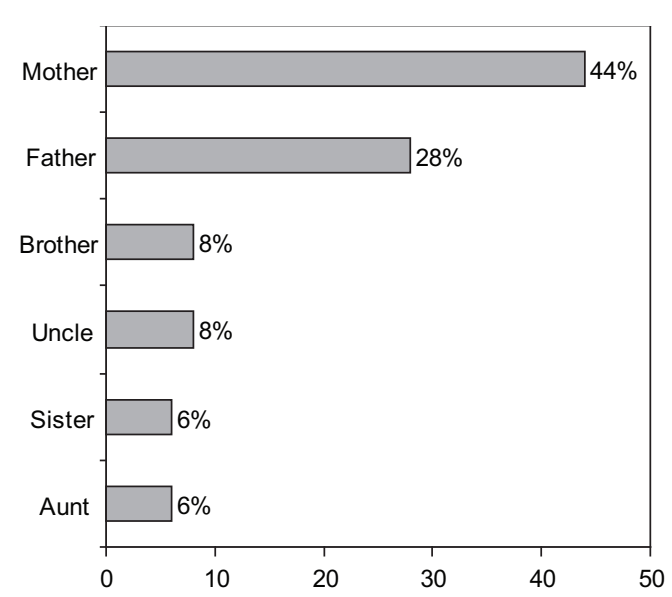

Fig.-1: Distribution of relations of study subjects with affected persons $(n=50)$

Among the 50 subjects carrier status of 5 persons $(10 \%)$ were known from before. That is hemoglobin electrophoresis was done before they were included in the present study, which reflects awareness of the general population especially relatives of thalassemia patients regarding the carrier status of thalassemia. Carrier detection status of relatives of thalassemia patients is shown in Pie chart-01.

Distribution of pallor among the study subjects is described in Pie Chart -02. In the present, 9 subjects $(18 \%)$ were mildly pale and 41 subjects $(82 \%)$ were not pale.

Pie-chart-03 depicts that NESTROFT resultsamong the study subjects. It was positive in $60 \%$ of study subjects.

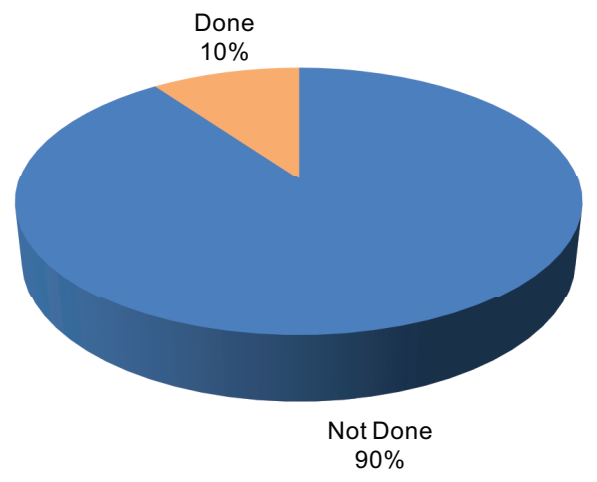

Fig.-2: Distribution of carrier detection status of study subjects.

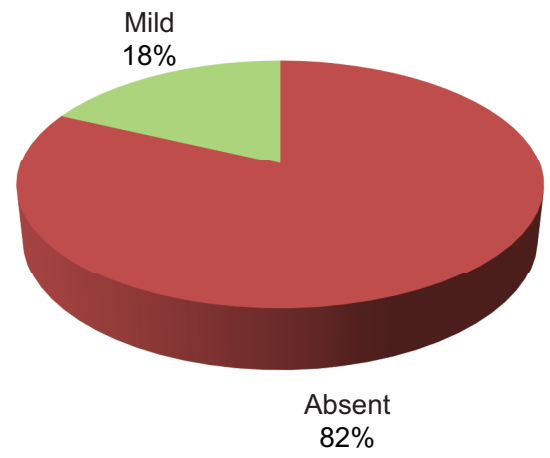

Fig.-3: Distribution of pallor among the study subjects.

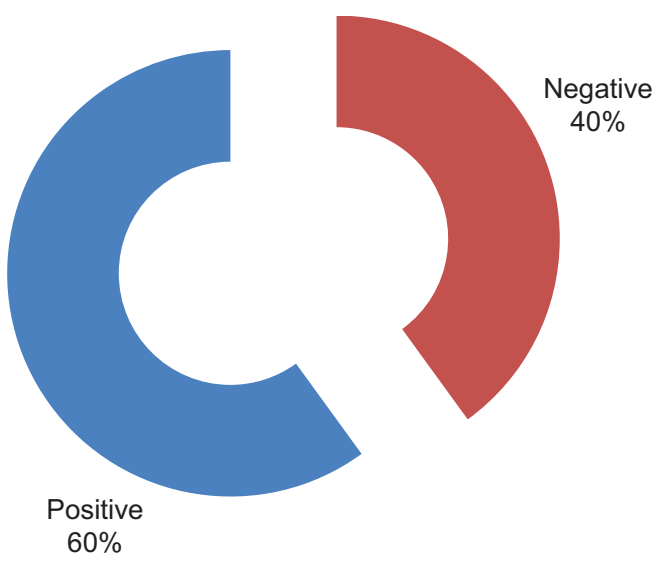

Fig.-4: Distribution of NESTROFT results among the study subjects.

Bar Chart-02 describe the 27 (54\%), 2(4\%), 11(22\%) of study subjects were detected respectively as ${ }^{2}$ thalassemia trait, $\mathrm{Hb}-\mathrm{E}$ disease, $\mathrm{Hb}-\mathrm{E}$ trait by $\mathrm{Hb}-$ electrophoresis, while $20 \%$ were normal. 


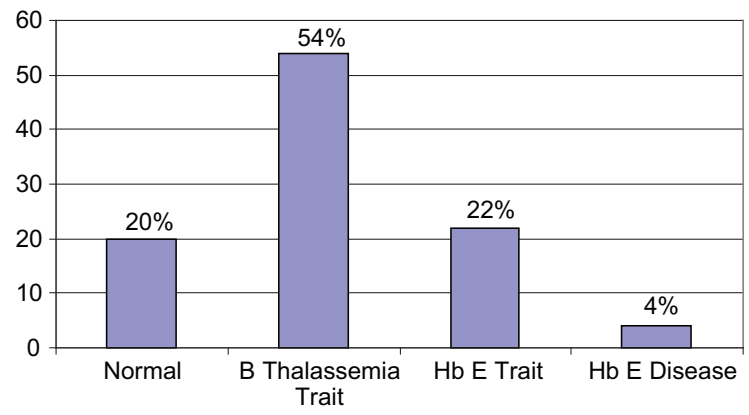

Fig.-5: Distribution of $\mathrm{Hb}$ electrophoresis results $(n=50)$

Bar Chart-03 shows distribution of hemoglobin electrophoresis results ignoring $\mathrm{Hb}-\mathrm{E}$ disease and $\mathrm{Hb}$ E trait. Among total 37 cases, $27(73 \%)$ cases were detected as ${ }^{2}$ - thalassemia trait and $10(27 \%)$ cases were normal on hemoglobin electrophoresis.

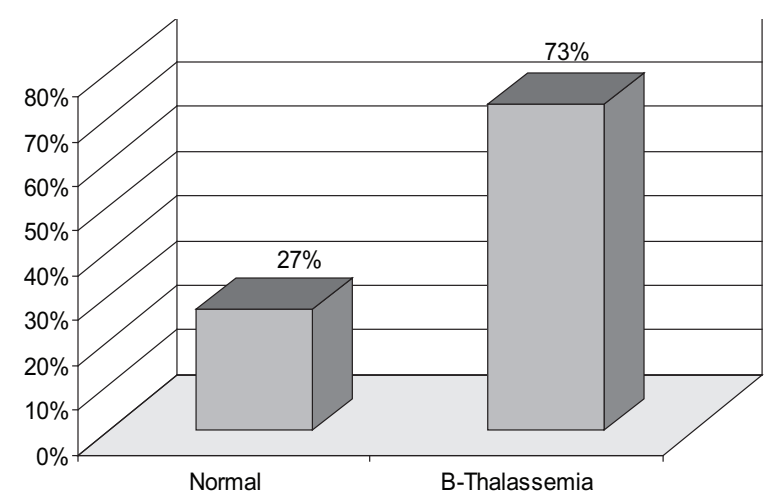

Fig.-6: Distribution of Hb electrophoresis results $(n=37)$

Table-03 describes the distribution of normal and abnormal hemoglobin on $\mathrm{Hb}$ - electrophoresis among the total 50 subjects. Here, $80 \%$ patients were detected to have abnormal hemoglobin on Hb-Electrophoresis.

\section{Table-III}

Distribution of normal and abnormal hemoglobin on Hb-electrophoresis $(n=50)$

Hb-Electrophoresis Frequency Percentage (\%) Result

\begin{tabular}{lcc}
\hline Normal & 10 & 20.0 \\
Abnormal & 40 & 80.0 \\
\hline Total & 50 & 100.0 \\
\hline
\end{tabular}

Table-04 shows distribution of pallor by NESTROFT results with $\mathrm{X}^{2}$ significance among the total 50 subjects. About $89 \%$ of the patients with mild pallor were detected NESTROFT positive, while among the subjects with normal hemoglobin about $54 \%$ were NESTFORT positive.Pearson's Chi-square test was done to find out the association between pallor and NESTROFT results. However, just significant was found $(\mathrm{P}=0.05)$. Fisher's Exact test was also just significant $\mathrm{P}-0.05$.

Table- 05 describes that $20 \%$ of subjects with normal hemoglobin and $70 \%$ of subjects with abnormal hemoglobin pattern were NESTROFT positive. Pearson's Chi-square test was done to find out the association between abnormal hemoglobin pattern and NESTROFT result. Highly significant association was found $(\mathrm{P}<.01)$. Fisher's Exact test was also significant $\mathrm{P}=0.006(\mathrm{P}=<.01)$.

Table-06 depicts the distribution of $\mathrm{Hb}$ electrophoresis results by NESTROFT with $\mathrm{X}^{2}$ significance $(\mathrm{n}=50)$. It shows that among the ${ }^{2}$ thalassaemia traits, $92.6 \%$ were NESTROFT positive, while among the normal patients, only $20 \%$ were NESTROFT positive. Pearson's Chi-square test done to find out the association between NESTROFT and $\mathrm{Hb}$-Electrophoresis results. It was found to be statistically highly significant $(\mathrm{P}<0.001)$.

Table-07 describes the distribution of $\mathrm{Hb}$ electrophoresis results by NESTROFT with $\mathrm{X}^{2}$ significance $(\mathrm{n}=37)$

Among 27 cases of beta-thalassemia trait, NESTROFT was found positive in 25 (92.6\%) subjects and $2(7.4 \%)$ cases were found NESTROFT negative; among 11 cases of $\mathrm{Hb}-\mathrm{E}$ trait the test was found positive in $1(9.1 \%)$ and was negative in 10 (90.9\%) subjects ; among 2 cases of Hb-E diseases all the subjects i.e. $100 \%$ were found NESTROFT positive; among 10 normal subjects $2(20 \%)$ were found positive and $8(80 \%)$ were found negative. Pearson's Chi-square test was done to find out the association between NESTROFT and ${ }^{2}$-thalassemia carrier. It was found to be statistically highly significant $(\mathrm{P}<.001)$. Fisher's Exact test was also highly significant $\mathrm{P}=0.000(\mathrm{P}=<.01)$. 
Table-IV

Distribution of pallor by NESTROFT results with $X^{2}$ significance $(n=50)$

\begin{tabular}{|c|c|c|c|c|c|c|}
\hline \multirow[t]{3}{*}{ Pallor } & \multicolumn{4}{|c|}{ Nestroft Result } & \multirow{2}{*}{\multicolumn{2}{|c|}{ Total }} \\
\hline & \multicolumn{2}{|c|}{ Positive } & \multicolumn{2}{|c|}{ Negative } & & \\
\hline & $\mathrm{n}$ & $\%$ & $\mathrm{n}$ & $\%$ & $\mathrm{n}$ & $\%$ \\
\hline Mild & 08 & 88.9 & 01 & 11.1 & 09 & 100.0 \\
\hline Absent & 22 & 53.7 & 19 & 46.3 & 41 & 100.0 \\
\hline Total & 30 & 60.0 & 20 & 40.0 & 50 & 100.0 \\
\hline
\end{tabular}

$\mathrm{X}^{2}=3.817 . \mathrm{df}=1 . \mathrm{P}=0.051$. Just Significant

Table-V

Distribution of normal and abnormal Hb-electrophoresis results by NESTROFT ( $n=50)$

\begin{tabular}{|c|c|c|c|c|c|c|}
\hline \multirow{3}{*}{$\begin{array}{l}\text { Hb-Electrophoresis } \\
\text { Result }\end{array}$} & \multicolumn{4}{|c|}{ Nestroft Result } & \multirow{2}{*}{\multicolumn{2}{|c|}{ Total }} \\
\hline & \multicolumn{2}{|c|}{ Positive } & \multicolumn{2}{|c|}{ Negative } & & \\
\hline & $\mathrm{n}$ & $\%$ & $\mathrm{n}$ & $\%$ & $\mathrm{n}$ & $\%$ \\
\hline Normal & 02 & 20.0 & 08 & 80.0 & 10 & 100.0 \\
\hline Abnormal & 28 & 70.0 & 12 & 30.0 & 40 & 100.0 \\
\hline Total & 30 & 60.0 & 20 & 40.0 & 50 & 100.0 \\
\hline
\end{tabular}

$\mathrm{X}^{2}=8.333 . \mathrm{df}=1 . \mathrm{P}=0.004$. Highly Significant

Table-VI

Distribution of Hb-electrophoresis results by NESTROFT with $X^{2}$ significance $(n=50)$

\begin{tabular}{|c|c|c|c|c|c|c|}
\hline \multirow{3}{*}{$\begin{array}{l}\text { Hb-Electrophoresis } \\
\text { Result }\end{array}$} & \multicolumn{4}{|c|}{ Nestroft Result } & \multicolumn{2}{|c|}{ Total } \\
\hline & \multicolumn{2}{|c|}{ Positive } & \multicolumn{2}{|c|}{ Negative } & & \\
\hline & $\mathrm{n}$ & $\%$ & $\mathrm{n}$ & $\%$ & $\mathrm{n}$ & $\%$ \\
\hline Normal & 02 & 20.0 & 08 & 80.0 & 10 & 100.0 \\
\hline B-thalassaemia trait & 25 & 92.6 & 02 & 7.4 & 27 & 100.0 \\
\hline $\mathrm{Hb} \mathrm{E}$ trait & 01 & 9.1 & 10 & 90.9 & 11 & 100.0 \\
\hline $\mathrm{Hb} \mathrm{E}$ disease & 02 & 100.0 & 00 & 0.0 & 02 & 100.0 \\
\hline Total & 30 & 60.0 & 20 & 40.0 & 50 & 100.0 \\
\hline
\end{tabular}

$X^{2}=31.829$. $d f=3 . P=0.000$. Highly Significant.

\section{Table-VII}

Distribution of Hb-electrophoresis results by NESTROFT with $X^{2}$ significance $(n=37)$

Hb-Electrophoresis

Nestroft Result

Total

\begin{tabular}{|c|c|c|c|c|c|c|}
\hline \multirow[t]{2}{*}{ Result } & \multicolumn{2}{|c|}{ Positive } & \multicolumn{2}{|c|}{ Negative } & \multirow[b]{2}{*}{$\mathrm{n}$} & \multirow[b]{2}{*}{$\%$} \\
\hline & $\mathrm{n}$ & $\%$ & $\mathrm{n}$ & $\%$ & & \\
\hline Normal & 02 & 20.0 & 08 & 80.0 & 10 & 100.0 \\
\hline B-thalassaemia trait & 25 & 92.6 & 02 & 7.4 & 27 & 100.0 \\
\hline Total & 27 & 73.0 & 10 & 27.0 & 37 & 100.0 \\
\hline
\end{tabular}

$X^{2}=19.498 . \mathrm{df}=1 . \mathrm{P}=0.000$. Highly Significant. 


\section{Table-VIII}

Usefulness of NESTROFT in heterozygous beta- thalassaemia: comparison of data with previous studies.

\begin{tabular}{|c|c|c|c|c|c|c|c|c|c|}
\hline & $\begin{array}{l}\text { Singh }^{19} \\
\text { et al } \\
(2008) \\
\end{array}$ & $\begin{array}{c}\text { kattamis }^{14} \\
\text { et al } \\
(1981) \\
\end{array}$ & $\begin{array}{c}\text { mehta }^{17} \\
\text { et al } \\
(1988) \\
\end{array}$ & $\begin{array}{c}\text { Gorakshaker }^{18} \\
\text { et al } \\
(1990) \\
\end{array}$ & $\begin{array}{c}\text { Raghavan }^{21} \\
\text { et al } \\
(1991) \\
\end{array}$ & $\begin{array}{c}\text { Thomas }^{22} \\
\text { et al } \\
(1996) \\
\end{array}$ & $\begin{array}{c}\text { Manglani }{ }^{10} \\
\text { et al } \\
(1997) \\
\end{array}$ & $\begin{array}{c}\text { Maheshwari6 } \\
\text { et al } \\
(1999) \\
\end{array}$ & $\begin{array}{c}\text { SiIrichotiyakul } \\
\text { et al } \\
(2004) \\
\end{array}$ \\
\hline Sensitivity (\%) & 97.7 & 98.4 & 95.0 & $98-100$ & 95.5 & 98.4 & 94.4 & 91.0 & 97.6 \\
\hline Specificity (\%) & 83.3 & 91.0 & 82.1 & $82-84$ & 87.0 & 66.6 & 64.2 & 95.0 & 72.9 \\
\hline $\begin{array}{l}\text { Positive Predictive } \\
\text { Value (\%) }\end{array}$ & 95.5 & 91.3 & 73.1 & 50.0 & 70.5 & 81.5 & 97.6 & 55.0 & 33.6 \\
\hline $\begin{array}{l}\text { Negative Predictive } \\
\text { Value }(\%)\end{array}$ & 90.9 & 98.3 & 97.0 & $99-100$ & 98.3 & 96.5 & 35.3 & 99.0 & 99.5 \\
\hline
\end{tabular}

Sensitivity, specificity, positive and negative predictive values of the test were calculated as validity statistics by the following formulae:

Sensitivity: $100 \times \mathrm{TP} \div(\mathrm{TP}+\mathrm{FN})$

Specificity: $100 \times \mathrm{TN} \div(\mathrm{TN}+\mathrm{FP})$

Positive predictive value: $100 \times \mathrm{TP} \div(\mathrm{TP}+\mathrm{FP})$

Negative predictive value: $100 \times \mathrm{TN} \div(\mathrm{TN}+\mathrm{FN})$

Here, $\mathrm{TP}=$ True positive i.e. have disease and have positive test. $\mathrm{FP}=$ False positive i.e. no disease but have positive test. $\mathrm{TN}=$ True negative i.e. no disease but have negative test. $\mathrm{FN}=$ False negative i.e. have disease but have negative test.

In this study, sensitivity of NESTROFT was $92.6 \%$ and specificity was $80 \%$, predictive value of a positive test was $92.6 \%$ and predictive value of negative test was $80 \%$.

\section{Discussion:}

Any programme for the prevention of Cooley's anaemia requires, as a preliminary step, the reliable identification of young people with thalassemia. Screening for beta- thalassemia trait is extremely difficult. This is mainly because of the heterogeneity of beta- thalassemia variants ${ }^{17}$. In spite of these difficulties, many attempts have been made to establish a screening test capable of detecting all betathalassemia variants. Various screening tests for carrier screening have been developed, viz. Determination of red cell indices, $\mathrm{HbA}, \mathrm{HbA}^{2}$ and $\mathrm{HbF}$ level estimation; however, all these techniques are time consuming and expensive for population screening.

In the present study, mean age was $30.12 \pm 10.02$ years and female subjects predominated, they constitute $56 \%$. Carrier status of $10 \%$ of study subjects was known from before. That is hemoglobin-electrophoresis was done before the persons were included in the present study, which reflects awareness of general population especially relatives of thalassemia regarding carrier of thalassemia.

In this study, $18 \%$ of study subjects were found mildly pale. Among them 2 were found normal on haemoglobin electrophoresis. They were not further investigated for detection of iron deficiency anaemia, as we know that iron deficient subjects may be NESTROFT positive. Among the rest of the pale subjects, there were 3 betathalassemia trait, $2 \mathrm{Hb}-\mathrm{E}$ trait and $\mathrm{Hb}-\mathrm{E}$ disease.

From the result of this study it was shown that NESTROFT was successful in detecting $92.6 \%$ of subjects of beta- thalassemia trait. It was also shown that $100 \%$ of $\mathrm{Hb}-\mathrm{E}$ disease was detected.

Table -08 shows the usefulness of NESTROFT in heterozygous beta- thalassaemia along with comparison of data with previous studies.

The present study found the NESTROFT to be more sensitive though not as specific, which correlates with other studies. Table-08 compares the sensitivity, specificity, positive and negative predictive values of the NESTROFT in the present study with those of other similar studies. All the previous reports have shown a sensitivity that is above $91 \%$, the specificity has varied from $64.2 \%-95 \%$. The sensitivity reported in other studies (Table-08). The specificity in the present study was $80 \%$, which is comparable to obtained by Mehta et al. ${ }^{17}$ Gorakshakar et al ${ }^{18}$ and

Singh et $\mathrm{al}^{19}$. The negative predictive value of the test in carriers during the present study was $80 \%$. The result is low but comparable with the study of Singh et al. ${ }^{19}$. Manglaniet $\mathrm{al}^{10}$ reported much lower value 35.5\%. Kattamis et al, ${ }^{14}$ Mehta et al, ${ }^{17}$ Gorakshakar et al ${ }^{18}$ and 
Sirichotiyakul et al, ${ }^{20}$ who reported negative predictive values of $98.3 \% .97 .0 \%, 99-100 \%, 98.3 \%, 96.5 \%$, $99.0 \%$ and $99.5 \%$ respectively.

In the present study, the test led to both high sensitivity and specificity; this is a desirable factor for judging the effectiveness of a test. Calculation of the negative predictive value in the test helps to rule out the possibility of beta-thalassemia trait in the general population. The application of this test for screening the cases before further investigations would reduce financial implications faced in performing other costly tests on the general population. The positive predictive value of the test has significance in a particular population with high prevalence of the disease. The positive predictive value was high $(92.6 \%)$ and comparable to the studies conducted by Kattamis et $\mathrm{al}^{14}$ and Singh et al, ${ }^{19}$ who reported values of $91.3 \%$ and $95.5 \%$ respectively; higher then $73.1 \%$ reported by Mehta et al, ${ }^{17} 50 \%$ reported by Gorakshaker et al, ${ }^{18}$ $705 . \%$ reported by Raghavan et al, ${ }^{21} 81.5 \%$ reported by Thomas et al, ${ }^{22} 55 \%$ reported by Maheshwari et al, ${ }^{6}$ and $33.6 \%$ reported by Sirichotiyakul et al ${ }^{20}$ and lower than $97.6 \%$ reported by Manglani et al. ${ }^{10}$

Although detection of the thalassemia trait using NESTROFT was successful in $92.6 \%$ of subjects with this trait. It also gave a false positive test in $20 \%$ of the normal individuals, which is quite comparable with $18.5 \%$ reported by Gomber et al. ${ }^{23}$ Although this test is easy to perform, fast, cheap and does not require sophisticated equipment, there are certain limitations of this test. As observed during the study, it gives false positive results in the case of patients with pallor. This would affect the specificity of the test in a population with high incidence of nutritional anaemia. Therefore, subjects positive with NESTROFT need to undergo further investigations to confirm the diagnosis. The test also needs careful standardization.

In this study NESTROFT showed high sensitivity and specificity, also high negative predictive value. NESTROFT has thus emerged as an inexpensive, most sensitive and specific test of population screening for the beta-thalassemia trait, and is considered suitable for large scale use in developing countries like
Bangladesh which has limited financial and technical resources.

\section{References :}

1. Khan WA. Thalassemia in Bangladesh. DS (Children) H journal 1999; June-December, 15(1\&2). 42.44.

2. Haque MS, Alam MA, Khan, W A et al. Thalassemia situation in Dhaka Shishu Hospital. Dhaka Shishu (Child) Hosp J 1999; 15:30-6.

3. World Health Organization. Hereditary disease programme: Guideline for the control of haemoglobin disorders. Geneva. WHO. 1994.

4. Khan WA, Banu B, Amin SK etal.Prevalence of beta-thalassaemia trait and $\mathrm{Hb}-\mathrm{E}$ tait in Bangladeshi school children and health burden of thalassaemia in our population. Dhaka Shishu (Children) Hospital journal 2005;21(1):1-7.

5. Begum JA, Amin SK, Khan WA, Selimuzzaman M, Sharmin S, et al. Evaluation of naked eye single tube red cell osmotic fragility test (NESTROFT) in detecting beta-thalassaemia trait. Dhaka Shishu (Children) Hospital Journal 2005;21(2): 44-48.

6. Maheshwari M, Arora S, Kobra M et al. Carrier screening and penatal diagnosis of beta-thalassaemia. India paedatr 1999;36:1119-24.

7. Shine I, Lal S.A strategy to detect b-thalassemia minor. Lancet 1977;1:692-694.

8. Ghosh A, Woo JSK, Wan CW. Machenry C, Wong V, Ma HK, et al. Evaluation of a prenatal screening procedure for b-thalassemia carriers in Chinese population based on the mean corpuscular volume (MCV). Prenatal Diag 1985;5:59-65.

9. Rogers M, phelan L, Bain B. Screening criteria for b-thalassemia trait in pregnant women. J Clin path 1995;48 1054-1056 .

10. Manglani M, Lokeshwar MR, Vani VG et al. NESTROFT an effective sceening test for beta-thalassaemia trait. Indian Paediatr 1997;34:702-7.

11. Klee GG, Fairbank VF, Pierre RV et al. Routine erythrocyte measurement in diagnosis of iron deficiency anaemia and thalassemia minor. Am J ClinPathol 1976;66: 870-7.

12. Bessman JD, Glimer PR, Gardner FH. Improved classification of anemia by MCV and RDW. Am J ClinPathol 1983;80(3): 3372-76.

13. Sukumaran PK. Thalassemias. J Assoc Phys India 1978;26: 627635 .

Rogers M, phelan L, Bain B. Screening criteria for b-thalassemia trait in pregnant women. J Clin path 1995;48 1054-1056 .

14. Kattamis C, Efremove G, Portrakul S. Effectiveness of one tube osmotic fagility screening in detecting b-thalassemia trait. J Med Genet 1981; 18:266-270.

15. Mahadik C, Kapadia C, Yagnic H, Sukumaran PK, Merchant S. One tube osmotic fragility as a useful screening test for thalassemia carriers- A field experience. Indian J Hematol 1986; 4: $62-64$. 
16. Mehta BC, Gandhi S, Kamath P. Survey of childen of Lohana community in Bombay for b Thalassemia trait and deficiency. Indian J Hematol 1987; 7: 63-66.

17. Mehta BC, Gandhi S. Mehta JB, et al. Naked eye single tube red cell osmotic fragility test for beta-thalassaemia: population survey. Indian J Haematol 1988; 6: 187-90.

18. Gorakshaker AC, Colah R, Nadkarni A, et al. Evaluation of the single tube osmotic fragility test in detection of B-thalassaemia trait. Natl Med J India 1990;3: 171-3.

19. Singh SP, et. al. Effectiveness of red cell osmotic fragility test with varying degrees of saline concentration in detecting betathalassemia trait. Singapore Med J 2008; 49(10):823-6.
20. Sirichotiyakul S. Tantipalakorn C, Sanguansermsri T, et al. Erythrocyte osmotic fragility test for screening of alphathalassaemia-1 and beta-thalassaemia trait in pregnancy. Int $\mathrm{J}$ GynaecolObstet 2004; 86: 347-50.

21. Raghavan K, Lokeshwar MR, Birewar N, et al. Evaluation of maked eye single tube red cell osmotic fragility test in detecting beta-thalassaemia trait. Indian pediatr 1991; 28:469-72

22. Thomas S, SrivastaveA,Jeyaseelan and HaemoglobinopathiesAn evaluation against a high performance liquid chromatography method. Ind J Med Res 1996; 104; 194-7.

23. GomberS,Sunjeev,MadanN.Validity of NESTROFT in screening and diagnosis of beta thalassemia Trait.J Trop pediar, 1997;43:3636. Thalassemia International Federation Editors. Guidelines to the Clinical Management of Thalassemia. $2^{\text {nd }}$ ed. 2007. 